\section{WINTERING SITES OF WALLCREEPER Tichodroma muraria ON THE EAST ADRIATIC COAST}

\section{Prezimovališča skalnega plezalčka Tichodroma muraria na vzhodni obali Jadrana}

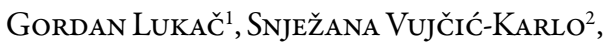 \\ Zlatko RuŽanović ${ }^{3}$, IVANA ADŽIĆ ${ }^{1}$, \\ Marijan MilovaC ${ }^{1}$, Roberto STELKo ${ }^{4}$
}

1 Public Institution Paklenica National Park, dr. Franje Tuđmana 14a, HR-23244 Starigrad-Paklenica, Croatia, e-mail: sluzba-zastite@paklenica.hr

2 National Museum Zadar, National History Department, Medulićeva 2, HR-23000, Zadar, Croatia, e-mail prirodoslovni.odjel@nmz.hr

3 Public Institution Kornati National Park, Butina 2, HR-22243, Murter, Croatia

4 Public Institution Natura Histrica, Riva 8, 52100 HR-Pula, Croatia

Wallcreeper Tichodroma muraria was observed during cold winters in different parts of Croatia, along the Adriatic coast, on islands as well as inland. Their origin remains unknown, but they may belong to the population nesting in the Alps or in Dinaric parts of Bosnia and Herzegovina and Montenegro. The overwintering along the Adriatic coast was explored during field observations, but also from the literature and museum data. The field investigations were carried out in Istria, North Dalmatia, Paklenica NP, Kornati NP and central Dalmatia, Krka NP. In total, 96 observations were made: 35 specimens from museum collections and literature and 61 during field research. The Wallcreeper was observed in Velika and Mala Paklenica canyons in Paklenica NP during cold winters, but not during milder winters. In the Paklenica $\mathrm{NP}$, the earliest individuals were observed on $10 \mathrm{Oct}$ and the latest on $28 \mathrm{Apr}$. On the complete east Adriatic coast and in Croatian inland, the earliest record was made on 6 Sep and the latest on 2 May. There are 5-10 individuals overwintering in Paklenica National Park.

\section{Introduction}

Wallcreeper Tichodroma muraria nests on calcareous cliffs of high altitude mountainous habitats in Central Europe and in Asia Minor and East Asia (Hernandez et al. 1997). Its European range extends from the Pyrenees in the west to the Carpathians in the east. In the Alps, it nests at altitudes ranging from $350 \mathrm{~m}$ to $2500 \mathrm{~m}$ a.s.l. The only nesting sites on Mediterranean islands are the cliffs of Corsica. It was observed in central and west Asia during the breeding season from $4700 \mathrm{~m}$ a.s.l. in Pamir to $5000 \mathrm{~m}$ a.s.l. in Tibet. Outside the nesting season it was observed in Ladakh up to $6400 \mathrm{~m}$ a.s.l. (Voous 1962 , Cramp \& Perrins i 993, SNOW \& Perrins I 998, GLUTZ von Blotzheim \& BAUer 2001, DANKo 2002). The lowest altitude nesting sites in Austria are at $540 \mathrm{~m}$ a.s.l. (SACKL \& SAMWALD 1997), in Slovenia near Črni kal at $400 \mathrm{~m}$ a.s.l. (GEISTER I 995) and in Slovakia from $400 \mathrm{~m}$ a.s.l. (SANIGA I 995). Its wintering sites cover wide alpine valleys of east and south Styria (SAmwald 1975, STANI i98 I, Puntigam 1985) and the Mediterranean coast from Gibraltar to the Black and Azov Seas. There were several winter observations in Sardinia, Sicily, Cyprus, Balearic Islands along with winter observations from Algeria, Malta and Israel (Glutz von Blotzheim \& BAUER 200I). During spring migration, one bird was observed on a gravel sandbar of the Mura River, Austria, feeding on insects in April 1994 (SAMWALD \& RINGERT 2015). There are some data regarding its nesting sites in Central Dalmatia, Croatia, but without specifying precise locations (KRALJ 1997).

From mid-July, adults depart from nesting sites before juveniles towards their wintering sites (GLUTZ VON BLOTZHeim \& BAUER 200I). The closest known breeding sites are in Bosnia and Herzegovina 30-50 $\mathrm{km}$ away from wintering sites on the Adriatic coast.

\section{Slovenia}

According to BirdLife InTernational (2015), 200-300 pairs breed in Slovenia. GeISTER (1995) recorded Wallcreeper as rare in Slovenia, found in only 12 UTM squares. It was observed in the Julian Alps and Karavanke Mts at an altitude of 2,109 m a.s.l. and on Mt Triglav (2,864 m a.s.l.) (GREgori i 977, Matvejev I 983 ). Its nests were positioned on shady and damp parts of cliffs. An irregular nesting site at $400 \mathrm{~m}$ a.s.l. near Črni $\mathrm{kal}$ is among the lowest nesting altitudes recorded so far in Europe (Geister I995, SANiga I995). Movements to lower parts of Slovenia and Slovenian inland were recorded in the wintering period near settlements with high church towers and buildings (GEISTER I 995).

\section{Austria}

In Austria, it breeds regularly in the eastern and northern Alps, and rarely in central Alps, between 540 and $2000 \mathrm{~m}$ a.s.l. A couple of observations were made during the breeding periods at $2600 \mathrm{~m}$ a.s.l. The 
majority of habitats in this area are calcareous cliffs and wet canyons (SACKL \& SAMWALD 1997). In southern Austrian lowlands, Wallcreeper was observed during winter in quarries (STANI 1976, WÖHL 1977, SACKL \& SAMWALD 1997) and only exceptionally on the banks of the Mura River during its spring migration (W. STANI in litt.). According to SAMwald \& RingerT (2015), the Wallcreeper is present in climatically favourable breeding habitat throughout the year.

\section{Croatia}

In Istria, the Wallcreeper was not registered according to literature (SCHIAvUZZI I 887, RUbiniČ 1996) until the end of the $20^{\text {th }}$ century. The three most recent three observations date back to the 2008-2016 period (DURDin 2008, Tout 2016). Typical winter observations were recorded in the Gulf of Kvarner from November to January at three locations. One observation was made at Veli Lošinj (Lošinj Island) in November 1963, and another two in the area around Rijeka (KRONEISL 1949,
SUŠić et al. 1988, RUCNER 1998). The data from museum collections confirm five observations in Gorski kotar (Sušić et al. 1988, GRBAC \& KRALJ 2008). According to MAŠTrović (1942), Wallcreepers were observed in northern Dalmatia between the beginning of October and the end of March on steep cliffs along the Zrmanja River valley. Last observation around the Zrmanja River dates to March 2010 (ŠupraHA et al. 2013). In Paklenica National Park, RUCNER (1998) observed 10 individuals in the Mala Paklenica canyon on 13 Oct 1967.

In central Dalmatia, Wallcreepers were observed in the canyons of the Krka and Čikola Rivers (Radović et al. 2004), on the slopes of Mt Mosor (MAšTrović 1942), on rocks near Omiš and along the Cetina River on 7 Nov 1966 (RUCNER I 998). There is one record from Split (KRPAN 1960); it was caught during the autumn migration on 23 Nov 1881 and eventually deposited in the Vienna Museum (KRALJ \& Tutiš I 996). Regarding the species' breeding in Central Dalmatia, a reference to it can be found in KRALJ (1997), but without specified location.

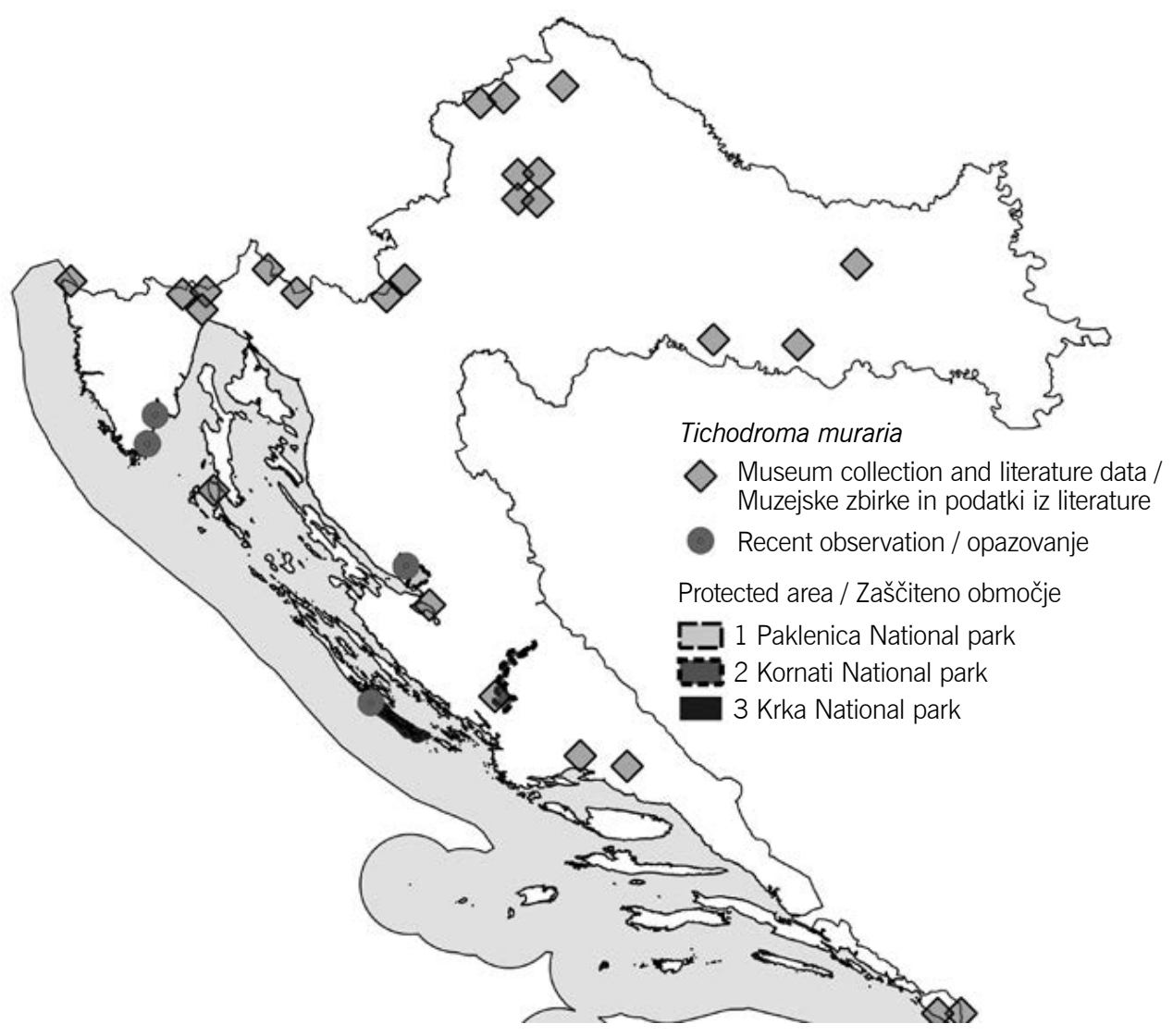

Figure 1: Winter, spring and autumn observations data of Wallcreeper Tichodroma muraria in Croatia

Slika 1: Zimska, spomladanska in jesenska opazovanja skalnega plezalčka Tichodroma muraria na Hrvaškem 


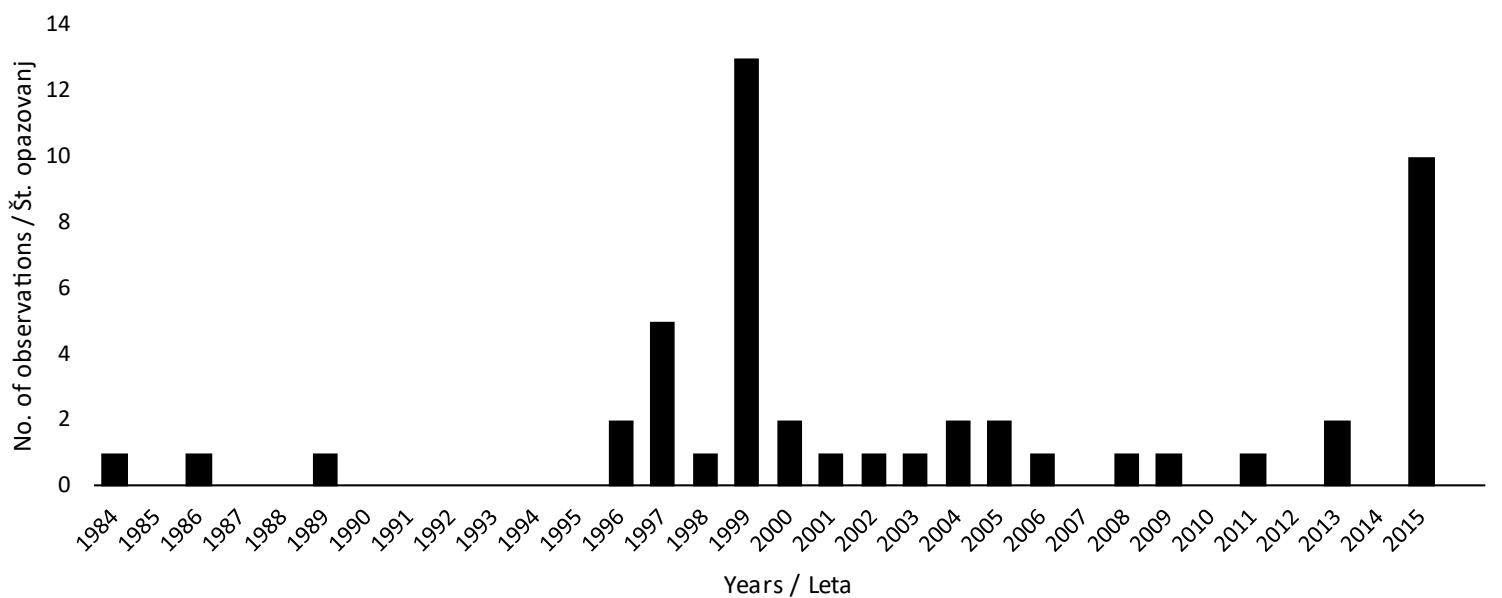

Figure 2: Temporal distribution of records of Wallcreeper Tichodroma muraria in this study

Slika 2: Časovna porazdeltiev opazovanj skalnega plezalčka Tichodroma muraria v tej raziskavi

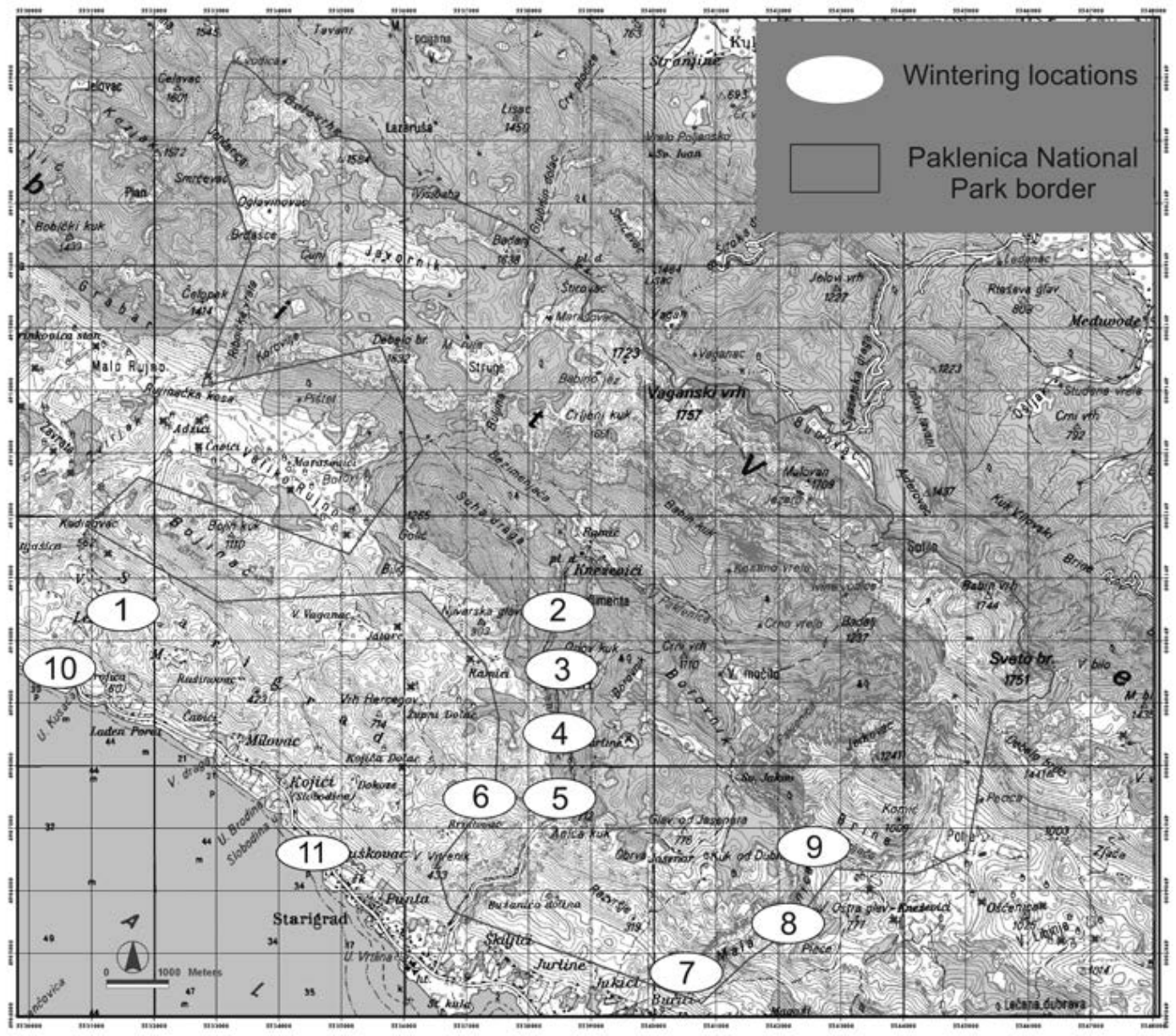

Figure 3: Wintering sites of Wallcreeper Tichodroma muraria in Paklenica NP

Slika 3: Prezimovališča skalnega plezalčka Tichodroma muraria v NP Paklenica 
Seven observations were made in southern Dalmatia; the specimens were deposited in museum collections, but have not been preserved until the present day (MAŠTrović 1942). Only four have been preserved in the ornithological collection of the Dubrovnik Museum (LUKAČ \& BALTIĆ 200I). There is a specimen stored in the ornithological collection in Metković, originating from spring 1956 (RUCNER I998).

Also, there are 18 records from the spring, autumn and winter periods, recorded at different locations of Croatian inland, predominantly from the surroundings of Zagreb. MARIć (in litt.) reports on a particularly interesting finding from Ivanščica, north-west Croatia, in the middle of a forest path, on 17 Oct 2007.

\section{Bosnia and Herzegovina}

Wallcreeper nests in Mt Prenj, from where records of young nesting individuals originate from the $19^{\text {th }}$ century (REISER 1939, OBRATIL 1967). According to REISER (1939), there are 19 records from Bosnia and Herzegovina, 6 of them originating from the JuneAugust nesting period and 13 from the migratory and wintering periods. The southernmost wintering observations were recorded in the Neretva valley, Čapljina and Hutovo blato locations, in the beginning of the $20^{\text {th }}$ century. As pointed out by RUCNER \& OBRATIL (1973), it is a possible nesting bird of Maglić, Volujak and Zelengora. In the 2000-2012 period, Wallcreeper apparently bred in the mountains of Želeća, Vlašić, Visočica, Prenj and Čvrsnica. The breeding population was estimated at 50 to 100 pairs (KotrošAn et al. 2012, NGO GREENVAY 2013).

\section{Montenegro}

Regular winter observations of Wallcreeper were made in Boka Kotorska (MAšTrović I 942). Five individuals were caught in December, January, February and March (2 males and 3 females). Wallcreeper is a resident bird in Montenegro according to SAVELJIĆ \& JovičEvić (2015).

Data regardingwinteringsites and vertical migrations of Wallcreeper are scarce for Croatia and its surrounding area. Therefore, based on winter observations, published literature and museum collections, we tried to summarise the data about the wintering sites along the east Adriatic coast and Croatian inland.

\section{Study area and methods}

The areas under investigation were: Istria, north Dalmatia, Paklenica National Park, Kornati National Park, central Dalmatia and Krka National Park. A total of 2040 winter fieldwork days were conducted in the 1985-2015 period in Istria, Paklenica NP in 1995-2015, Krka NP in 2012-2015 and Kornati NP in 2000-2007.

Istria was divided into 52 UTM $100 \mathrm{~km}^{2}$ squares, as part of the breeding bird atlas surveys (LUKAČ \& STELKO 2016). Southern Velebit and Paklenica National Park were researched in the 1984-1996 period within 296 days of fieldwork (LUKAČ \& STIPČEvić i997). In 1995-2015, Paklenica NP was divided into $1751 \mathrm{~km}^{2}$ squares and surveyed in the nesting season, during spring and autumn migration and in winter within 1000 field days. In Krka NP, transects were done

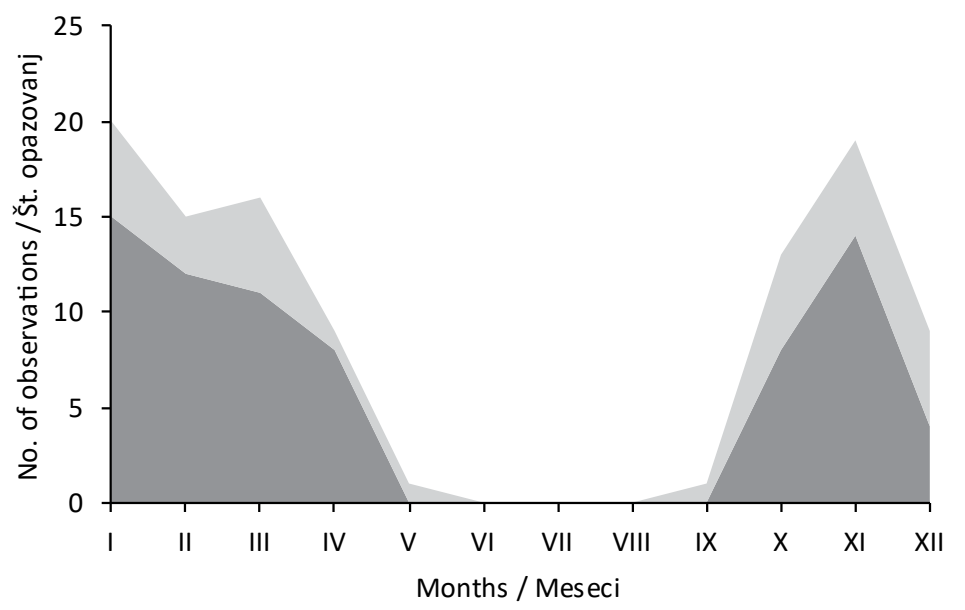

Total number of observations based on recent field observations and literature data

Recent field observations

Figure 4: Seasonal distribution of Wallcreeper Tichodroma muraria records in Croatia

Slika 4: Sezonska dinamika opazovanj skalnega plezalčka Tichodroma muraria na Hrvaškem 
between Skradin and Skradinski buk, at Roški slap and in the Čikola canyon near the road. In Kornati NP, islands were visited during the breeding and wintering seasons, as well as during spring and autumn migration, when more than 500 field days were conducted. Islands were visited by boat, especially steeper cliffs. Museum data include collections from the Croatian Natural History Museum in Zagreb, Ornithology Department of the Croatian Academy of Sciences and Arts, Natural History Department of the National Museum Zadar, Natural History Museum in Split and Dubrovnik Museum.

\section{Results}

We identified 96 records: 61 during our field work and additional 35 records in museum collections in Croatia and Austria. 52 of these observations were classed as recent, i.e. after 1984 (Figures $1 \& 2$ ).

The most recent records reported from Istria relate to the observations made during the wintering and spring migration periods. Wallcreeper was recorded six times in Labin, Marina area, in the 1985-2005 period in two squares during the months of February, March, January and December. The last observation was made in autumn during the migration period near Pula (28 Oct 2015), whereas three were made by other ornithologists in the 2008-2016 period (DURDIN 2008, Tout 2016).

The only recorded observation from Kornati National Park dates from 17 Mar 2005, when one individual was observed on a steep cliff of Mana Island during spring migration. Individuals were observed on rocks and cliffs of the Velika and Mala Paklenica canyons between 10 Oct and $28 \mathrm{Apr}$ in 11 squares.
Additional observations were made in three squares outside the boundaries of the National Park (Figure 3). The highest number of observations was made in 1999 in Paklenica National Park, when the first individual was spotted on $10 \mathrm{Oct}$ and then regularly observed until 23 Nov. In 2015, the first individuals were observed on $10 \mathrm{Feb}$, while the last observation was made on 9 Apr. Generally, observations of Wallcreeper in Paklenica National Park since 1984 have been irregular, with only short periods of regular observations made during the winter period from 1999-2006.

The frequency of observations through the wintering period (Figure 4) shows the highest numbers in January and February. First observations were made in the first decade of September and the last in the first decade of May. Observations in the nesting season, from June until August, are missing. The biggest number of individuals observed in the Mala Paklenica canyon in Paklenica National Park was 10 individuals during their autumn migration on $13 \mathrm{Oct}$ 1967 (RUCNER I998).

The occurrence of this species in the South Velebit mountain range as its overwintering site is restricted to an altitudinal range of $30-700 \mathrm{~m}$ a.s.l. So far, there have been no observations at altitudes higher than $700 \mathrm{~m}$ a.s.l. Most observations, a total of 36 (Figure 5), occurred at altitudes between 90 and $320 \mathrm{~m}$ a.s.l.

The habitat where Wallcreepers were recorded most often was, based on NATURA 2000 classification, 8210 Carbonate rocks with chasmophytic vegetation and 8130 West Mediterranean thermophilous scree which include thermophilous plant species such as: Quercus ilex, Quercus pubescens, Fraxinus ornus, Carpinus orientalis, Ostrya carpinifolia, Celtis australis, Rhamnus intermedia, Frangula rupestris, Ficus carica,

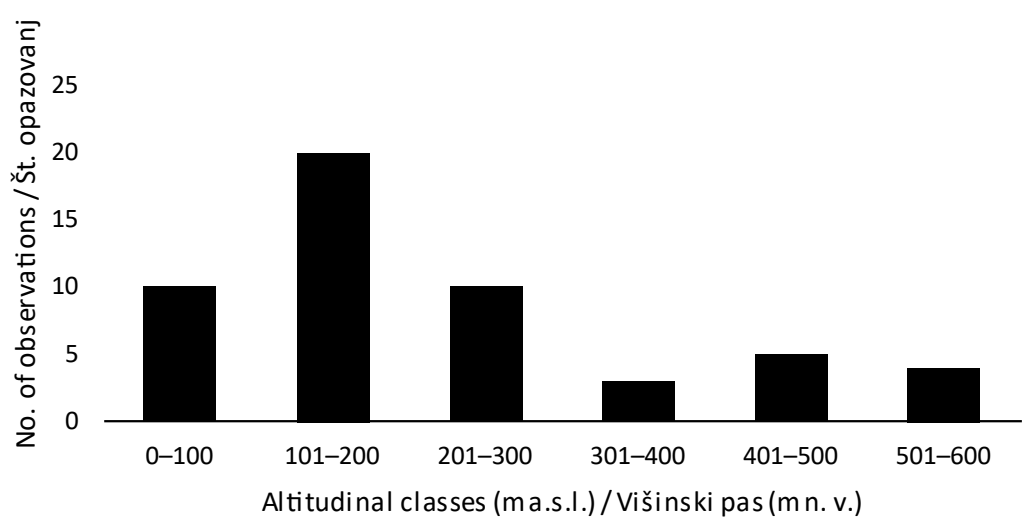

Figure 5: Altitudinal distribution of Wallcreeper Tichodroma muraria records in Croatia

Slika 5: Višinska porazdelitev opazovanj skalnega plezalčka Tichodroma muraria na Hrvaškem 
Prunus mahaleb. We observed Wallcreepers while they were searching for food along shady places with dripping water, on cliffs rich with crevices and on large limestone blocks in the Velika and Mala Paklenica canyons. Even though there is a stream running through the canyon in autumn, winter and spring, we have very seldom recorded Wallcreeper on rocks near or protruding from the stream. Based on the collected data, it appears to be more frequent during colder winters, whilst during mild winters observations are missing.

\section{Discussion}

Wallcreeper is a rather irregular wintering bird species on its overwintering sites in Paklenica National Park (LUKAČ 2OI I). It was specified as a nesting species in Central Dalmatia by KRALJ (1997), overwintering in Dalmatia and in inland from October until March (MAŠTrović 1942). Wallcreeper is not listed as a breeding species in the Red book of birds of Croatia (TuTIš et al. 2013). Low temperatures and high snow cover limit the food availability and force birds to migrate further south in search for new food sources. The majority of observations of Wallcreeper were made in cold winter with snow near the coast in north Dalmatia (e.g. in 996, 1999, 2005).

Observations from South Velebit and Paklenica National Park were more frequent and similar to experiences in the Mediterranean part of Slovenia and in Styria. The earliest observation of Wallcreeper in its wintering site was recorded in Croatian inland, in Zagreb, on 6 Sep 1900 and the latest in early May (2 May 1929, Moslavina, Nova Gradiška), when they start migrating from their winter sites. Irregular observations since 1984 point out that this bird species overwinters in the researched area every second or third year (LUKAČ \& STIPČEVIĆ I 997, LUKAČ 20I I). In the Mala Paklenica canyon it may be observed at the earliest in the first decade of October (10 Oct 1999); it leaves the area at the latest in the third decade of April (28 Apr 1984). It is possible that one part of birds from Istria, Gorski kotar and the Gulf of Kvarner arrive from the Alps and another part of the wintering population (birds observed in Dalmatia) from mountainous parts of Bosnia and Herzegovina and Montenegro.

It is important to highlight additional sites where Wallcreeper overwinters irregularly such as eastern Istria, Kvarner, Gorski kotar, Krka, Čikola and Cetina River canyons, Split, Neretva mouth and Dubrovnik surroundings (MAŠTROVIĆ I 942, KRPAN I 980 , KRALJ \& TUTIŠ I 996, RUCNER I 998). MAŠTROVIĆ (1942) reports on six individuals caught in Dubrovnik area and 5 individuals caught at wintering sites in Boka Kotorska, Montenegro. Scarce findings from Lošinj Island, 11 Nov 1963 (Kvarner Region), and one observation recorded in Kornati National Park, 17 Mar 2005, show that some individuals fly all the way to north Adriatic islands. Winter dispersal and migration was recorded in the Mediterranean in Sicily, Sardinia, Malta, and Balearic Islands and even at several locations in North Africa (Glutz von Blotzheim, BAUER 200I). Findings from Croatian inland indicate its presence during the winter in Gorski kotar, North-west Croatia (Zagreb area, Karlovac, Hrvatsko Zagorje, Ivanščica) and Central Croatia (Slavonia, Kutjevo).

Based on our field observations, we estimate that 5-10 individuals overwinter in Paklenica National Park, based on best expert opinion. It is rather difficult to estimate overwintering population on the entire east Adriatic coast, as recent fieldwork was restricted to only small part of the area researched.

\section{References}

BIRDLIFE INTERNATIONAL (2015): IUCN Red List for birds. - [http://www.birdlife.org/datazone/userfiles/ file/Species/erlob/supplementarypdfs/22711234 tichodroma_muraria.pdf], 01/12/2015.

Cramp S., Perrins C. M. (eds.) (1993): Handbook of the Birds of Europe the Middle East and North Africa. The Birds of the Western Palearctic. Vol. VII Flycatchers to Shrikes. - Oxford University Press, Oxford.

DANko Š. (ed.) (2002): Birds distribution in Slovakia. VEDA, Bratislava.

Durdin C. (2008): Istria 16-19 March 2008. - [http://www. honeyguide.co.uk/pdfs/2008Istria.pdf], 04/12/2016.

GrbaC I., KraLJ J. (2008): Katalog zbirke ptica Hrvatskog prirodoslovnog muzeja. - Natura Croatica 17 (suppl. 1): 1-226.

Geister I. (1995): Ornitološki atlas Slovenije. - DZS, Ljubljana.

Glutz von Blotzheim U.M.,BAuer K.M.(200I): Handbuch der Vögel Mitteleuropas. Band 13/2, Passeriformes 4. teil (Sittidae-Laniidae). -Aula Verlag, Wiesbaden.

GrEgORI J. (1977): Ekološki in favnistični pregled ptičev severozahodne Slovenije. Larus, 29-30, 33-81.

Hernandez A., Hauri R., Saniga M. (1997): Wallcreper. pp. 651. In: Hagemaijer E. J. M., Blair M. J. (eds.): The EBCC Atlas of European Breeding Birds. - T \& AD Poyser, London.

Kotrošan D., Drocić N., Trbojević S., Šimić E., Derović I. (2OI 2): Program IBA, Međunarodno značajna područja za ptice u Bosni i Hercegovini. - Ornitološko društvo „Naše ptice” interno izdanje za projekat „Evaluacija IBA područja Federacije Bosne i Hercegovine, Sarajevo.

KRALJ J. (1997): Ornitofauna Hrvatske tijekom posljednjih dvjesto godina. - Larus 46: 1-112.

Kralj J., Tutiš V. (1996): Samples of Birds from Croatia in the Ornithological Collection of the Natural History Museum in Vienna. - Natura Croatica 5: 25-51. 
KRONEISL R. (1949): Contributions to the ornithofauna of the upland region between Sava and Drava in Croatia. Birds of mountain Medvednica. - Larus 3: 305-352.

KRPAN M. (1960): Contribution to the study of the birds of the environs of Split. - Larus 13: 65-91.

KRPAN M. (1980): Srednje dalmatinska ornitofauna. - Larus 31-32: 97-156.

LUKAČ G. (20 I I): Atlas ptica Nacionalnog parka Paklenica. JU NP Paklenica \& HPM, Starigrad-Paklenica.

LUKaČ G., BALtić M. (200I): Diversity and richness of the ornithological collection of the wider Dubrovnik area (Croatia). - Natura Croatica 10 (4): 321-365.

LukaČ G., Stelko R. (20I6): Atlas ptica Istre. - JU Natura Histrica, Pula.

Lukač G., Stipčević M. (1997): Birds of National Park Paklenica. - Natura Croatica 6: 11-60.

Maštrović A. (1942): Die Vögel des Küstenlandes Kroatiens. I Bd. - Institut für angewandte Zoologie in Zagreb, Zagreb.

Matvejev S. D. (1983): Ptice Triglavskog nacionalnog parka i susednih predela. - Larus 33-35: 69-91.

NGO GREENVAY (2013): Crvena lista faune Federacije Bosne i Hercegovine. Nacrt izvještaja. - Sarajevo.

Obratil S. (1967): Pregled istraživanja ornitofaune Bosne i Hercegovine, I dio. - G.Z.M. BiH, Sarajevo, Prirodne nauke 5: 191-268.

Puntigam J. (1985): Ornithologische Beobachtungen, vorwiegend im Grazer Feld und in der Weststeiermark, in den Jahren 1980 bis 1983. - MAZ 34: 21-29.

Radović D., Leskovar K., Crnković R., Tutiš V., KralJ J. (2005): Inventarizacija ornitofaune, kategorizacija i valorizacija ptičjih vrsta i staništa NP Krka. - Zavod za ornitologiju HAZU, Zagreb.

ReISER O. (1939): Materialien zu einer Ornis Balcanica I. Bosnien und Herzegowina. - Annalen des Naturhistorischen Museums in Wien, Wien.

Rubinič B. (1996): Ptice doline reke Mirne v Istri na Hrvaškem, I del Gaviiformes - Charadrifformes. - Falco 10: 5-42.

Rucner D., Obratil S. (I973): Prilog poznavanju avifaune planinskog područja Maglića, Volujka i Zelengore. Larus 25: 61-93.

Rucner D. (1998): Ptice hrvatske obale Jadrana. - Hrvatski prirodoslovni muzej i Ministarstvo razvitka i obnove, Zagreb.

Sackl P., Samwald O. (1997): Atlas der Brutvögel der Steiermark. - Landesmuseum Joanneum, Graz.

SAMWALD F. (1975): Ornithologische Beobachtungen, vorwiegend in der Oststeiermark, in den Jahren 1973 und 1974. Jg. 4, 123-138.

SAMwald O., RingerT J. (2015): Mauerläufer Tichodroma muraria. pp. 684-686. In: Albegger E., SAmwald O., Pfeifhofer H. W., Zinko S., Ringert J., Kolleritsch P., Tiefenbach M., Neger C., Feldner J., Brandner J., Samwald F., Stani W. (eds.): Avifauna Steiermark Die Vögel der Steiermark. BirdLife Österreich Landesgruppe Steiermark, Leykam Buchverlags Ges. m. b. H. Nfg. \& Co. KG, Graz.

SANiga M. (1995): Seasonal distribution, altitudinal and horizontal migration of the Wallcreeper (Tichodroma muraria) in the Malá Fatra mountains, Slovak Carpathians. - Folia zoologica 44 (3): 237-246.
Schiavuzzi B. (I887): Materiali per una avifauna del Littorale austro-ungarico. - Bollettino della Società Adriatica di scienze naturali in Trieste 10: 154-183.

Snow D. W., Perrins C. M. (1998): The birds of the Western Palearctic. Concise Edition. - Oxford University Press, Oxford.

STANI W. (1976): Ornithologische Beobachtungen im Bezirk Leibnitz im Jahre 1975 (Aves). - Mitteilungen der Abteilung für Zoologie am Landesmuseum Joanneum 5 (2): $65-75$.

STANI W. (198I): Ornithologische Beobachtungen aus der Südsteiermark unter besonderer Berücksichtigung des Vogelschutzgebietes „Murstausee Gralla“ im Jahre 1980. - Mitteilungen der Abteilung für Zoologie am Landesmuseum Joanneum 10: 33-49.

Sušić G., RAdović D., BARTovsky V. (I988): Znanstvena zbirka ptičjih svlakova Zavoda za ornitologiju JAZU. pp. 37-88. In: MešTrov M., Sušić G. (eds.): Ornitologija u Hrvatskoj. -JAZU, Zagreb.

ŠUPRAHA L., BASREK L., BUDINSKI I. (2013): Inventarizacija ornitofaune rijeke Zrmanje. Zbornik radova Zrmanja 2010. pp. 190-204. In: BASREK L., ĐUĐ L. (eds.): Zbornik radova projekta "Istraživanje bioraznolikosti područja rijeke Zrmanje 2010"- Udruga studenata biologije BIUS, Zagreb.

Tout P. (2016): Wallcreeper and woodpecker break (Istria) 9-13 March 2016. - [http://www.honeyguide.co.uk/ documents/wallcreeperbreak2016.pdf], 04/12/2016.

Tutiš V., Kralj J., Radović D., Ćiković D., Barišić S. (2013): Crvena knjiga ptica Hrvatske. -Državni zavod za zaštitu prirode i Ministarstvo zaštite okoliša i prirode, Zagreb.

Voous K. H. (1962): Die Vogelwelt Europas und ihre Verbreitung. - Verlag Paul Parey, Hamburg.

WöHL E. (1977): Die Alpenbraunelle, Prunella collaris (Scopoli) als Wintergast an der Burgruine in Graz Gösting. - Mitteilungen der Abteilung für Zoologie am Landesmuseum Joanneum 6: 105.

Prispelo / Arrived: 2. 9. 2016

Sprejeto / Accepted: 6. 12.2016 